\title{
Existentialist Perspective: A Study of Bharati Mukherjee's Fiction The Holder of the World
}

\author{
Dr Savita Yadav \\ Assistant Professor \\ Satyawati College \\ University of Delhi \\ Delhi, India \\ yadavrahul3578@gmail.com
}

\begin{abstract}
The present study explores and analyses the existential perspective in Bharati Mukherjee's novel The Holder of the World; she tries to represent the fluid nature of immigrants due to frequent dislocations and relocations, which facilitate the characters to transform and assimilate into a new environment. The protagonist, Hannah Easton, discards nostalgic feelings and celebrates the latest opportunities in a liberal environment. Being a fearless, brave, and bold, spirited woman, she chooses her ways of life freely and accepts the consequences frankly. Bharati Mukherjee, one of the path breaking Indian American novelists and short story writers, has constantly made efforts to voice the immigrant experience of women. Hannah initially suffers from cultural shock, but being resourceful establishes her authentic existence by understanding the new environment utilising her full potential via free choices.
\end{abstract}

Keywords: Existentialism, Alienation, Stream of Consciousness, Individualism, Psyche.

Born in 1940 to Hindu Brahmin Bengali- speaking parents in an old East Bengal village, Faridpur, Bharati Mukherjee had established herself as an articulate, thoughtprovoking and socially committed writer. She moved to Calcutta, India and died in January 
2017 in Manhattan, New York City, New York, USA. Shortly after independence, at the age of eight, she lived with her family in London and Switzerland for three and a half years, becoming fluent in English. In 1951 the family returned to Calcutta, and Mukherjee joined the English - speaking Loreto Convent School, run by Irish nuns. Her parents supported her in all her intellectual efforts, and as a 'true feminist,' her mother guided and shaped her perceptions as an individual right from early childhood. She learned from her mother "the courage not to be bogged down by the cultural mores of the Indian society. Her mother was the first true feminist she had met in life. She had gained great things for women at a time when women were treated as mere slaves" (Stephen 15).

Bharati Mukherjee's characters in the fiction reveal tolerance, love, and harmony, where no community or sex is superior to another, and each individual has equal rights. They struggle to live with freedom and a search for the 'self' and existence. She projects her characters persistently struggling with their conflicting selves and the environment. She has also worked on various dimensions of pressures exerted by the complex nature and demands of the society in which modern man is inflicted. Her writings relate to Rogers assertion that: "the operation of inherent forces impelling each person to want to 'become' or 'realise' himself"' (qtd. in McDavid \& Harari 87). The present work attempts to explore Mukherjee's novel The Holder of the World in context with existentialist philosophy and investigate the existential perspective where there is a tendency in the characters to work with freedom and to exist in their own way.

Existential philosophy emerged in the writings of Kierkegaard and Jaspers and the later contributions of Heidegger, Sartre, and others. There is no single existential philosophy; existentialism instead is more oriented towards understanding the nature and meaning of man's existence. It emphasises that man is not a readymade machine; preferably, he has the freedom to make vital choices and to assume responsibility for his existence. It lays stress on 
the subjective experience as a sufficient criterion of truth. As stated by John Macquarrie and others, man exists before he acquires essence, a definite individuality. The difference is between 'being' and 'becoming.' Other things also exist, but man differs from them in that he is free to become a personality. Strong men transcend the oppressive discipline of a dull society and create their own values. They commit themselves to a cause to change the culture and overcome life's complexities while weak men make vain efforts to escape from them.

The consciousness of the concept "“exist' that inspired the word 'existentialism' was first articulated by Kierkegaard, and Nietzsche was among the first writers to expose the intimate relationship between experience, practice and the world that came to play a central role in existential philosophy" (Cooper 31). The single factor for existential thinkers is freedom which is almost a synonym of existence. In the $20^{\text {th }}$ century Jean-Paul Sartre, the French philosopher, adopted Kierkegaard's perspective, and for him, human action occurs within a zone of freedom. Sartre's assertion that 'existence precedes essence' means that "man first of all exists, encounters himself, surges up in the world - and defines himself afterward. If man, as the existentialists see him, is not definable, it is because to begin with he is nothing. He will not be anything until later, and then he will be what he makes of himself" (290).

Existentialism is concerned with how individuals relate to the objective world, other human beings and their sense of self. Recently, David Cooper argued that: “'existentialism' names a distinctive, and systematically coherent, picture of the world shared by a 'family' of thinkers." Generally, "existentialists assert the uniqueness of the human situation in the world (i.e., they reject a theoretically reductive philosophical naturalism). This situation is characterised by ambiguity and estrangement, but also by a sense of freedom and responsibility for meaning" (qtd. in Crowell 15). 
Human beings are prone to a sense of estrangement or alienation from the world. Martin Buber presented alienation, as the main subject, in his book I and Thou that the person who lives in an 'I-It' relation to the world lives in "severance and alienation," without a home, a dwelling in the Universe (58). The 'I' used for 'self' convey a deeply personal, subjective and familiar meaning while the 'It' is foreign and unknown, hence an alien presence. This estrangement is responsible for arousing the notion of existence and makes the name existentialism an appropriate one. Kierkegaard restricts the term "existence" to individual human beings where they are "infinitely interested in existing" and "constantly in the process of becoming" (253). For Macquarrie, existence means, "Man fulfils his being precisely by existing, by standing out as the unique individual that he is and stubbornly refusing to be absorbed into a system" (66). In its root sense, existence means 'standing out' or going beyond what he is in that moment or moulds one's life accordingly. Kierkegaard, in his works, calls the individual to come out from the crowd and bear the burden of his being upon himself. One should not seek help from theories and principles or the illusion of conventionality because the existence of each existent is 'distinct' and 'unique' from the existence of everyone else. The other more important aspect of existence is self-relatedness, which means the individual is the centre of everything and has to evolve his value system. It does not remain fixed or static keeps on changing with time.

For existentialists, "we have to start from freedom if we are to understand man" (Roubiczeck 122). Freedom means acting entirely by our own free will. For Sartre, "freedom and existence are indistinguishable. One does not first exist and then become free; rather, to be human is already to be free" (qtd. in Macquarrie 177). Kierkegaard, Nietzsche, and Jaspers call the term 'the public' 'the herd' and 'mass existence' respectively that works autocratically and becomes a barrier to inhibit freedom. Existentialists believe that individuals do not get or leave a well-structured universe with a coherent design. In their 
dealing with freedom, people are responsible for their choices, life plans, and the world. The inescapable reality of death gives meaning to existence. It is also the source of existential or normal anxiety. Existentialists sometimes seem preoccupied with death. It is in facing death that an individual is most likely to come to an understanding of life. Frankl sees "death not as a threat but as urging for individuals to live their lives fully and to take advantage of each opportunity to do something meaningful" (qtd. in Sharf 176). Accordingly, death awareness can lead to creativity and living entirely rather than facing fear and dread.

The novel depicts the story of a strong character that utilises her potential to counter the restrictive perspectives of gender, class, and culture and accept new possibilities of selfhood. Hannah Easton, the protagonist, is exposed to a wide range of experiences in the alien land of Mughal India. She was born and brought up in an orthodox Puritan society where she has been trained to suppress her passions, but unsatisfied by her mechanical and immanent existence, Hannah strives to transcend her 'daily activities' and create new meaning in her life. The novel focuses on Hannah Easton's unflinching quest for a liberated and meaningful existence. The individuality and self-confidence portrayed in Mukherjee's earlier novel Jasmine through the character of Jasmine are reflected in a broader dimension in The Holder of the World. The protagonist in Jasmine travels from East to West and undergoes a series of transformations and assimilation in the foreign land. Whereas Hannah's journey, "fraught with images of adventure, action and passion projects a sort of escape from the rigid claustrophobic Puritan world" (Myles 313). As a citizen of the New World, she undergoes the process of liberation from the West to the East within an "intricate, brilliantly rendered, constantly surprising mythology of time and identity, intellect and emotion" (Bagul 123). In the words of another critic: "The novel has a wide canvas that sweeps across continents, cultures, and religions. The West meets the East and the New World falls in love with the Old World" (Stephen 78). 
The narration in the novel is similar to that of Nathaniel Hawthorne's The Scarlet Letter (1850), where Hester Prynne, like Hannah Easton, tries to assert her unique and independent spirit by challenging the imposed rigid Puritan rules and crossing the thresholds. Both of them face similar circumstances, and both transform themselves according to the required situation and condition. Hester Prynne's Scarlet letter 'A' represents 'Adultery' for the Puritan world, but she, with her consistent efforts, transforms the same letter 'A' into 'Ability' or potential, which enables her to assimilate and exist in the same old Puritan world with dignity and authenticity. Similarly, Hannah Easton's Eastward journey, with the realisation of her full potential, transforms her in such a manner that an entirely new figure emerges out of her in the new world. The beauty and artistic perfection of the writer are reflected through a fine blend of fact and fiction, rationality, and emotion and the old and the new world. The writer has tried to represent women's issues in the context of history as well as contemporary times with the belief that "people are continually remaking their culture, and in so doing redefining the past, reconstituting the present and reconceptualising what they desire from the future" (Long 202).

The novel reverses the geographical movement of Jasmine in the sense that two American women Hannah Easton and Beigh Masters, move from westward Salem, Massachusetts, to the eastward Coast of Coromandel, India, in the late seventeenth and late twentieth century, respectively. The writer focuses on the continuum of the immigrant experience moving from a small region into the vastness of the three time zones simultaneously--- the past, the present and the future. Beigh's patient reconstruction of Hannah's story is meant to suggest that there were passages to and fro from India even in colonial New England and that lives have been lived across cultures in all centuries. Moreover, Mukherjee seems to be telling her readers that if we care to bring together the stories scattered in history, we will come to realise how intertwined lives are. To say merely 
that West was West and the East was East and that the two had scarcely met is contested in the works of Bharati Mukherjee. On the contrary, as Venn Iyer comments: "everything in history . . . is as tightly woven as a Kashmiri shawl” (189). Hannah's story clearly establishes that even a woman born in colonial New England could constructively internalise India and Indianness into her psyche.

Hannah Easton was the only surviving child of Edward and Rebecca Easton in the Massachusetts Bay Colony. Hannah lost her father at the tender age of one and lost her mother, Rebecca, a twenty-two-year-old widow, when the Nipmuc laid siege to Brookfield in 1675. The little daughter had a disturbing memory of her mother, which haunted her wherever she went. Her mother had deserted her in a Brookfield forest to run away with her American-Indian lover, and a Nipmuc woman drops her on the doorsteps of the Fitch family. The little girl was brought up under the rigid norms of Puritan society. Hannah Easton, a sensitive and bold girl, imagines the vulnerable position of her mother as a widow in orthodox Puritan society and loves her "more profoundly than any daughter has ever loved a mother" (30).

Hannah grows up as an adopted child of the devout Puritan couple, Robert and Susannah Fitch, who try to insert in her all the conventional wisdom and housekeeping tips supposedly required for an agreeable bride. Hannah, a revolutionary figure like Jasmine, refuses to accept the imposed rules and regulations of Puritan society since she wants to shape her own fate. A human being's striving for transcendence (Kierkegaard) is at the very core of existential thinking, and one's true identity depends on the ways in which one tries to resolve the challenges presented by life. Hannah, in her dreams, learns the subversive alphabet from Rebecca - her biological mother: "“A is for Act, my daughter!'. . ' $\mathrm{B}$ is for Boldness,' Hannah pledged. ' $\mathrm{C}$ is for Character. D is for Dissent, $\mathrm{E}$ is for Ecstasy, $\mathrm{F}$ is for 
Forage . . .'And . . .'I is for Independence,' said Hannah” (54). This reveals Hannah's craving for authentic existence in society.

Hannah settled in a modest two-storied house on Herbert Street in Salem with her foster parents Robert and Susannah Fitch, who rears her up with love and affection and channel her energy through needlework that gives her fame and recognition provides her enough strength to take bold steps in life. Her fame and charming personality endear her to the masses: "Temptation dogged the sensuous Hannah everywhere ...” Her embroidery work becomes 'the embodiment of desire' and reveals ". . . the conflict she tried so hard to deny or suppress" (42). Her potential is reflected when she receives a marriage proposal from the Pynchon's, one of New England's upstanding families, but Robert Fitch politely refuses the offer for her own good as well as for the good of the country because "If Solomon Pynchon's marital overture had been accepted, the history of the United States would have been profoundly altered" (57). Hannah's search for her existence would also have ended with her marriage.

Hannah readily agrees to marry the dashing Irish adventurer Gabriel Legge, mainly because he appears to be the type who could take her into the new unknown world, though he was not very trustworthy. Hannah's intimate friend Hester Manning, who had been receiving treatment from Gabriel, was found dead one day. As Sandhya Rao Mehta says: "Hannah instinctively agrees to marry Gabriel not as much out of love for him as a way of squeezing out of her constrictive frontier society" (195). Hannah, in search of independence, is unconsciously imitating her mother's behaviour. Her motive to liberate herself from feudal Puritan society by marrying Gabriel Legge - who claimed to be the son of a shipowner ferrying family from Old England to the New England, and thus enter into the new exotic alien world is similar to her mother: "Gabriel Legge with his tales of exotic adventure was as close to the Nipmuc lover as any man in Salem; she sought to neutralise her shame by 
emulating her mother's behaviour" (69). Beigh interprets and rationalises Hannah's decision related to marriage in terms of appropriateness of time: "We do things when it is our time to do them. They do not occur to us until it is time; they cannot be resisted, once their time has come. It's a question of time, not motive" (70). When one applies one's potential to exist, one has to strive with the external forces of time, fate and circumstances. Hannah's consent for marriage with Gabriel was an attempt to transcend the conventional norms of the Puritan world and explore her capabilities in a new land with free will. She knew that the motif of her life could only be fulfilled with the help of such a frank and generous person who could create a whole world of imagination to celebrate every moment of life. Existentialists believe that women in a patriarchal set-up are deprived of their freedom and suggest a kind of human existence where they can make their choice as free and responsible individuals.

Gabriel and Hannah leave for Salem to England and get settled in Stepney. This movement is significant in the sense that Hannah enters the colonial centre from the colony (margin). When Gabriel goes out on his mysterious missions, she engages herself in a nurse's duty, using all the nursing lessons. She applied her capacities in a way that helped her to assimilate into an entirely different environment. Meanwhile, Gabriel proves to be a 'compulsive seafarer' who remains away from home for months, and at the age of twentythree, Hannah comes to know of Gabriel's death. She is denied the conventional widowhood role of Puritan society. There is no place for a pirate's widow and an Indian lover's daughter in old Salem. She is offered the job of a governess in Cambridge by Herbert, a research scholar in the Royal Society, but Gabriel Legge's sudden appearance closes all alternate prospects. Gabriel proposes that she accompany him to India, where he has joined as a junior factor in the East India Company. Hannah finds this an excellent opportunity to realise her potential in a new land and attain her individuality. 
Hannah migrates to Coromandel Coast of Southeastern India as the wife of Gabriel, the East India Company man, with great enthusiasm and curiosity: "Her curiosity was robust. She wanted to earn, not inherit, dignity. She moved on. Without regrets" (90). She confronts the truth of British industrialists in India: "They had not come to India in order to breed and colonise, or even to convert. They were here to plunder, to enrich themselves (under the guise of a Royal Charter) and pay their fees to the ruling nawabs" (99-100). Hannah's motif, however, is entirely different. She has come to adjust and assimilate in a foreign land with her fluid identity, and her primary concern in this new world appears to be a quest for a meaningful life: "She was alert to novelty, but her voyage was mental, interior. Getting there was important, but savoring the comparison with London or Salem, and watching her life being transformed, that was the pleasure" (104). She requires time to resolve her errands "-oh, so many errands!--in this vast new jungle" (105) and dares to transform her life according to her convenience in the new land.

Hannah knows that life in the Indian sub-continent is entirely different and that she cannot use her own western parameters to evaluate this world. During their voyage, her husband had endlessly talked about the plural society in India, its caste, class and religious diversity, and freedom to speak different languages and worship different gods and goddesses. She was excited to arrive on land where everybody was free to follow their own religious beliefs, and unlike Puritans, there were no firm rules and regulations to pursue. The fact that she has relatives here in this country provides her much comfort and assurance that she will be able to exist here by transforming herself according to the environment. She shows hatred for those English women like Martha Ruxton and Sarah Higginbotham, who pretend to be noble and superior over the local community and display English snobbery and arrogance characteristic of the women in the colonies. Hannah is a humanitarian soul who believes in the freedom and dignity of the people, which, according to her, formed the core of 
human existence. Where for Sartre, "it is the human condition, from the moment of first consciousness to the moment when death wipes it out. I am my own freedom: no more, no less" (qtd. in Bakewell 6).

Marriage to Gabriel fails to fulfil Hannah's desires, and the imaginary world created by him through his stories proved far from real. Hannah, however, keen to assimilate into a new culture, takes every opportunity that comes her way to strengthen her belongingness and pleasure: "She walked the streets and even the back lanes of Black Town, just as she had walked in Salem. She heard music from the upper floors of the sheds that passed for their housing and smiled back at the faces of youngsters as they gathered to watch her" (132-133). All such minute observations of native life provide her ease and comfort. She wanted to know and understand the gap between the two cultures.

Hannah comes to understand the full description of the term 'bibis' from old company wives like Martha and Sarah during her stay in Fort St. Sebastian, where it was the primary topic of conversation among White Town women: "Any servant with a new sari . . meant a good serving girl had passed over to bibihood. Bibis were simultaneously beneath notice, no more than cute little pets like monkeys or birds . . . and devious temptresses, priestesses of some ancient, irresistible and overpowering sensuality" (131). The bibi, Hannah is told, has to be admitted as a natural consequence of married life since "Accommodation was synonymous with expatriate femininity" (134). Hannah evaluates herself and says, "I am neither wife nor queen' ... A bibi had the right, the duty, to live for love. Gabriel's black bibi had seized happiness for Gabriel and for herself; a bibi had the power to laugh in the face of a firangi wife" (254).

Hannah always wanted to live life on her own terms, and India seemed appropriate for Hannah's freedom-loving spirit. Whereas the house she lived in New England appeared more like a "barricade to stop encroachment" (118) the house in Fort St. Sebastian "was built to 
entice crystal-bright tropical starlight, spume-scented breeze, bugs, birds and butterflies through its huge barred windows" (119). Hannah's earlier act of rejecting cultural stereotypes and restrictions in Puritan England leads her to imbibe the fresh spirit of freedom in a new land, India. She does not feel any remorse or longing for Gabriel Legge even when there is an apprehension that he drowned in a cyclone in the Bay of Bengal. She now looked forward to her own expansion: "The Coromandel had started something as immense as a cyclone deep inside her body and mind. To let Gabriel go was also to let herself expand" (163). Hannah finds a good friend in the form of her Indian Ayah, Bhagmati, who serves to fill the emotional gap created by Gabriel. In his absence, she begins to talk more freely to her maid Bhagmati and learns from her about Indians and their beliefs. Led by Bhagmati, Hannah finally begins to comprehend the world of the natives. Bhagmati brings her the glimmerings of understanding of an ancient civilisation. She narrates fragments from The Ramayana, and the stories once again ignite Hannah's memories related to her own experience of abduction, betrayal, and vengeance. Sita's captivity reminds Hannah of the life of Mary Rowlandson as well as her mother. While in Bhagmati's orthodox translation of the myth, "Sita is the selfsacrificing ideal Hindu wife" (173). Hannah imagines and interprets Sita as "a woman impatient to test herself, to explore and survive in an alien world" (174). The life events of Sita fascinate Hannah because she can identify them with her own life. Like Hannah, Sita was a deserted girl where she "adjusted to life as a king's adopted daughter and a prince's wife as willingly as Hannah had to her girlhood in Salem" (174). Sita's life changes when the situation arrives before her to choose between continuing her life in a palace or breaking away and trying out new surroundings. Sita chooses the latter. The incident of Sita's life when she proves her purity in a trial by fire finds an interesting parallel in Hannah's life, too being a trial by fire. Still, unlike Sita, she never withstands agnipariksha for the sake of her husband. The writer stresses that "only those people can survive in an alien world who are 
elastic and who can shape themselves according to the availability of space by improvising upon their native rules" (Murugesh 158). Like Jasmine, Hannah, too, has a vital element of adaptability. Her eagerness represents that she is ready to challenge the stereotypical beliefs, social organisation and "control mechanism" (Singh 65).

After her disappointment with Gabriel, Hannah continues her journey till she reaches Raja Jadav Singh of Devgad. The state of Devgad is "... a Hindu-ruled disfigurement on the Muslim map of South India, and a deeply embedded thorn in the flesh of Emperor Aurangzeb" (211). Hannah would have drowned when a bridge collapses, but Jadav Singh saves her, and afterwards, she becomes his 'bibi'. However, this incident is imperative for the total transformation of her personality. She enters the world of romance at first sight and enjoys a grand affair with Raja: "An angel counselled me, a fantasy governed me: bliss descends on the derangers of reason and intellect" (228). Raja provides Hannah with enormous opportunities and emotional comfort in life. It is this experience of being overwhelmed by love, of being possessed to the point of distraction that Hannah embraces with the totality of her being and little moral speculation: "In Massachusetts Bay, life had been so hard, the summer so short, that freaks of nature were given less opportunity to emerge and no comfort to thrive" (173). India opens new avenues of life for her. She attains her individual self in a complete sense with her Indian lover. She is aware of the transformation of her whole personality: "With Jadav Singh, she'd finally accepted how inappropriate it was in India - how fatal - to cling, as White Towns tenaciously did, to Europe's rules. She was no longer the woman she'd been in Salem or London" (234).

Hannah and Jadav Singh continue to support each other to fight against the Nawab Haider Beg, Governor of Aurangzeb's state, who asked his commander Murad Farah to imprison Raja in order to seize the diamond and bring Hannah- the 'Firangi' lady to his palace. Jadav Singh had no option but to bundle Hannah and Bhagmati into one palanquin 
and anxious Raja into another. On their way to Nawab, Raja attacked the Mughal army. Hannah eventually kills Morad Farah, saves Jadav Singh's life and brings him back to Panpur. She decides to offer her life to end the war and goes to transact with the Emperor with a heartfelt appeal: "Oh, Great Emperor, build your city, build your mosques and your palace, but stop this war before it destroys the world! You speak of mercy, but where is the quality of your mercy?" (268-269). Her appeal, however, falls on deaf ears, and she is taken hostage by the Emperor, whom she scorns for his 'lust for vengeance.' Though Hannah fails in her mission for a truce between the Raja and the Emperor, she manages to steal the diamond from Aurangzeb's war tent and escape towards the fort of Panpur. She hands over the diamond to Bhagmati, who thrusts the world's most famous diamond into her dying womb. It is in her grave that they find the holder of the world of the seventeenth century.

Jadav Singh's death and Hannah's encounter with Emperor Aurangzeb make her mature in terms of her journey to the world of the mysterious East. Hannah's "courtship with the Raja indicates a relationship based entirely on Indian, 'Eastern' values and morality with little reference to the life left behind" (Murugesh 156). She is ready to project her Indian lover despite his dissociation from her. The suspension of morality and the openness to new experiences make Hannah confront Aurangzeb, who honoured her as "the Healer of the World" (20). Hannah, searching for liberation, rebels whenever the situation demands and charts out her own path. In the beginning, she rebels against her husband "for having a bibi but within a few months, she willingly becomes one herself, suspending all morality, all expectations of conventional relationships" (Mehta 197). She justifies the existentialist belief that individuals do not enter or leave a structured universe with a coherent design. It is in their dealing with the freedom that they create their own world. Hannah chooses freely to exist in her own way. 
Hannah's odyssey to India is full of adventure, action, and passion. She returns to her native land, not as a reformed American but a rebel living on the fringes of society. Cultural transformation helps Hannah to expand herself and to face life boldly. The novel ends with her return journey to Salem, where she locates her mother with her five Nipmuc children in a mental asylum and brings up her 'black' daughter Pearl Singh. She runs a multi-ethnic, multiracial family without any fear and pressure of Puritan society in Salem. Her odyssey is mental and 'interior' rather than physical. She undergoes various transformations to imbibe herself on alien land as Hannah Easton becomes Hannah Legge after her marriage, and Salem Bibi with Raja Jadav Singh: "In one rainy season, Hannah Legge had gone from woollen-clad English married woman on the Coromandel Coast to pregnant sari-wearing bibi of a raja; a murderer, a widow, a peacemaker turned prisoner of the most powerful man in India" (271). The love she got from Raja Jadav Singh strengthens her determination. She attains courage that enables her to face the 'holder of the world' - the 'Alamgir,' the Great Mughal Emperor Aurangzeb. Even Aurangzeb is fascinated by the personality of Hannah and hails her with a very precious title: "I call you Precious-as-Pearl” (270).

She ends up as Mukta, Bhagmati's word for 'pearl,' precious as a pearl in the court of Aurangzeb. Hannah frees herself from the confines of geographical and religious boundaries, social distinctions, cultural differences and linguistic hurdles and progresses to fulfil her quest for self-realisation. Beigh Masters recognises Hannah's potential and acknowledges her as a woman with a free spirit and having the extraordinary enthusiasm to progress in life. Hannah rejects the stereotypical world of Puritans and emerges as a real fighter in life. Malashri Lal's comment related to the protagonists of Bharati Mukherjee's fiction is very apt for Hannah Easton and Jasmine, as they are “. . . neither nostalgic for their personal past nor afraid of the unfamiliar present. The main strategy is adaptation without surrender". Also, women protagonists are “. . confident, sophisticated, poised -- who will not melt into ... 
mainstream but visibly expand the margins" (qtd. in Trikha 160). Hannah's whole personality undergoes a sea-change during her restless move from Salem to Stepney, Coromandel to Devgad and back to Salem.

Bharati Mukherjee establishes that a survivor goes with innovation and not conventionality and allows her characters to realise their potential as autonomous individuals in society. It is the only way by which they could achieve personal recognition and existence. Hannah repeatedly rejects patriarchal stereotypes and live a life of her own outside the home. The more she knows herself, the more confident she becomes. She assimilates and exists on foreign soil and their own native land and proves to be "a pure product of her time and place" (220).

The movement of the narrative is circular; the story ends with the same consequence as it opens, but "Hannah does not remain the same. . . . Hannah Easton buries her puritan past and emerges as a real fighter for life" (Murugesh 234). Hannah finds absolute contentment and joy on the adopted land, and it is the morality of this land that she carries along with her. She can now comprehend her own culture from a broader perspective. The West meets the East, and the new world falls in love with the old world. Beigh Masters aptly sums up Hannah's strength and potential in words: "Wherever she stayed, .. . she would have changed history, for she was one of those extraordinary lives through which history runs a four-lane highway" (189). Hannah's journey in The Holder of the World goes with Sartre's belief that "I have no predefined nature at all. I create that nature through what I choose to do." (qtd. in Bakewell 6). 


\section{Works Cited}

Bagul, A.S. The Fiction of Bharati Mukherjee. Chandralok Prakashan, 2007.

Bakewell, Sarah. At the Existentialist Cafe: Freedom, Being and Apricot Cocktails. Vintage, 2016.

Buber, M. I and Thou: Trans. R. Gregor Smith. Edinburgh: T. \& T. Clark, 1937. Print.

Cooper, David E. "Existentialism as a Philosophical Movement." The Cambridge Companion to Existentialism. Ed. Steven Crowell. Cambridge UP, 2013. 27-49.

Heidegger, M. Being and Time. Translated by J. Macquarrie and E. Robinson. Harper and Row, 1962.

Kierkegaard, S. Concluding Unscientific Postscript. Edited and translated by A. Hannay. Cambridge UP, 2009, pp. 182.

---. Philosophical Fragments/ Johannes Climacus. Translated by H.V. Hong and E.H. Hong. Princeton UP, 1985.

Lal, Malashri. "Bharati Mukherjee: The 'Maximalist' Credo.' Contemporary Indian English Fiction, edited by Kamal. N. Awasthi. ABS Pub., 1993, pp. 55-64.

Long, Elizabeth. The American Dream and the Popular Novel. Routledge and Kegan Paul, 1985.

Mandal, Somdatta, editor. Bharati Mukherjee: Critical Perspectives. Pencraft Books, 2010. Macquarrie, John. Existentialism: An Introduction, Guide and Assessment. Penguin Books, 1972.

McDavid, John W., and Herbert Harari. Psychology and Social Behaviour. Harper and Row Pub., 1974, pp. 87, 184.

Mehta, Sandhya Rao. “The Utmost Coasts Abroad: Hannah Easton's Quest in The Holder of the World." Indian Women Novelists, edited by R.K. Dhawan. Set 3. Vol. 3, Prestige, 1995, pp. 193-198. 
Mukherjee, Bharati.The Holder of the World. Random House P, 1993.

Murugesh, Shilpa. Identity Issues in the Novels of Bharati Mukherjee. Lap Lambert Academic Pub., 2016.

Myles, Anita. "Progression from Feminine to female in the Novels of Bharati Mukherjee." Perspective on Indian English Fiction, edited by Jaydipsinh K Dodiya. Sarup \& Sons, 2006, pp. 308-316.

Parameswaran, Uma. "A Review of The Holder of the World." World Literature Today, vol. 68, no. 3,1994, pp. 636-637.

Roubiczeck, Paul. Existentialism for and Against. Cambridge UP, 1964.

Sartre, Jean-Paul.Being and Nothingness: An Essay on Phenomenological Ontology.

Translated by H.Barnes. Washington Square P, 1992.

Sharf, Richard S. Theories of Psychotherapy \& Counseling. "Existential Therapy." Chap.5. $2^{\text {nd }}$ ed. Brooks/Code, 2000, pp. 166-210.

Singh Sushila. "Recent Trends in Feminist Thought." Indian Women Novelists. Ed. R.K. Dhawan. Prestige, 1991. 65.

Stephen, Stanley M. Bharati Mukherjee: A Study in Immigrant Sensibility. New Delhi: Prestige, 2010.

Tirkha, Pradeep. “Quest for Self and the Immigrant Experience in Bharati Mukherjee's Fiction” Women Writers in the Twentieth Century Literature, edited by Monika Gupta. Atlantic, 2000, pp. 153-166. 